\title{
Photochemical changes and oxidative damage in four foxtail millet varieties following exposure to sethoxydim
}

\author{
M.J. GUO, Y.G. WANG ${ }^{+}$, S.Q. DONG, Y.Y. WEN, X.E. SONG, and P.Y. GUO \\ Key Laboratory of Crop Chemical Regulation and Chemical Weed Control, Agronomy College, \\ Shanxi Agricultural University, Taigu 030801, China
}

\begin{abstract}
In order to assess its response to the herbicide, sethoxydim (SEY), seedlings of two foxtail millet (Setaria italica) hybrids were exposed to $0.75,1.5,3$, and $6 \mathrm{~L}$ (SEY active ingredient, ai) $\mathrm{ha}^{-1}$ for 7 and $15 \mathrm{~d}$. Our results showed that SEY reduced photosynthesis and oxidative stress in the hybrid millet (Zhangza) at the dosage below $1.5 \mathrm{~L}$ (ai) ha ${ }^{-1}$ (i.e., recommended dosage), whereas it caused death of Jingu 21 at all treatment dosages. In addition, we further explored the effect of SEY on PSI and PSII; the hybrid millet showed a greater tolerance to SEY and also the ability to recover. In conclusion, the hybrid millet seems to possess certain photosynthetic protection mechanisms which could reduce or eliminate the herbicide stress by increasing nonphotochemical quenching for dissipating excessive light energy under SEY-induced oxidative stress.
\end{abstract}

Additional key words: chlorophyll fluorescence; $\mathrm{P}_{700}$ parameters; reactive oxygen species; spring hybrid millet.

\section{Introduction}

Sethoxydim (2-[1-(ethoxyamino)butyl]-5-2-ethyl-thiopropyl-3-hydroxy-2-96 cyclohexen-1-one, SEY, NipponSoda, Japan) is one of the most widely used herbicides which is applied annually to agricultural land in China due to its good selectivity at low dosage (Xie et al. 2014, Sandín-España et al. 2015). SEY belongs to the cyclohexanediones family and is mainly applied to soybean, cotton, sunflower, and other broad-leaved crops for effective elimination of monocotyledonous species during post-emergence (Brinson 1990, Edwards 2005). These herbicides work by inhibiting plastid acetyl-CoA carboxylase (ACCase) of monocotyledonous species, and cause chloroplast bleaching, tissue necrosis, growth reduction, and plant death. Aicha et al. (2013) reported that SEY treatments decreased a lipid content during the lipid metabolism process, reduced fatty acid synthase (FAS) activity, and inhibited ACCase activity. Herbicides are very effective in controlling their targeted weeds in croplands; however, it is of great concern to understand their effects on non-targeted organisms.

Foxtail millet (Setaria italica), a member of the Poacea grass family, is a particularly important cereal and fodder crop (Zhang et al. 2012). Due to its high nutrition value and high digestibility (Kamara et al. 2009), foxtail millet has become one of the major food crops and staple food for the people in Northern China. However, weeds severely affect the yield and quality of this crop (Stoltz et al. 2014). The biggest challenge in weed control is lack of suitable herbicides for use in foxtail millet due to its sensitivity to herbicides. Currently, the hybrid foxtail

Received 9 January 2017, accepted 10 April 2017, published as online-first 18 May 2017.

+Corresponding authors; e-mail: tgwygn@126.com; pyguo126@126.com

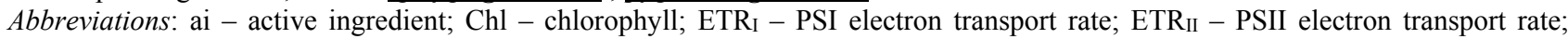
$\mathrm{F}_{\mathrm{v}} / \mathrm{F}_{\mathrm{m}}$ - maximum photochemical efficiency of PSII; $\mathrm{F}_{\mathrm{v}} / \mathrm{F}_{0}$ - potential activity of PSII; FM - fresh mass; MDA - malondialdehyde; $\mathrm{P}_{\mathrm{m}}$ - maximal $\mathrm{P}_{700}$ change; $\mathrm{q}_{\mathrm{P}}$ - photochemical quenching coefficient; ROS - reactive oxygen species; SEY - sethoxydim; $\mathrm{Y}_{\mathrm{I}}-$ photochemical quantum yield of PSI; $Y_{\mathrm{II}}-$ PSII effective quantum yield; $\mathrm{Y}_{\mathrm{NA}}$ - quantum yield of nonphotochemical energy dissipation due to accepter side limitation in PSI; $Y_{\mathrm{ND}}$ - quantum yield of nonphotochemical energy dissipation due to donor side limitation in PSI; $\mathrm{Y}_{\mathrm{NO}}$ - quantum yield of nonregulated energy dissipation in PSII; $\mathrm{Y}_{\mathrm{NPQ}}$ - quantum yield of regulated energy dissipation in PSII. Acknowledgments: Conceived and designed the experiments by Y.G. WANG and P.Y. GUO; data analysis: X.E. SONG and Y.Y. WEN; contributed reagents/material/analysis tools: S.Q. DONG; performed experiments and writing the paper by M.J. GUO. This work was supported by the Scientific and Technological Project in Shanxi Province, China (20150311016-2), the Science and Technology Key Research Project in Shanxi Province, China (2015-TN-09), the National Natural Science Foundation of China (31301269), the National Science and Technology Support Plan of China (2014BAD07B01), and the Program for the Top Young Innovative Talents of Shanxi Agricultural University (TYIT201406). 
millet "Zhangza" has been widely cultivated in China, because of its resistance to adversity, high yield, and rich nutritional value (Dong et al. 2014). The Zhangza 5 is a new hybrid variety, which was bred from A2 and the improved Jingu 21; moreover, the improved Jingu 21 was obtained from Jizhangzagu 1 and SR3522 (herbicideresistant "sethoxydim" genes) (Wang et al. 1997). The Jingu 21, which is one of the main varieties of foxtail millet in China and has been widely grown in the major foxtail millet production regions of northern China for 30 years, is a high-quality conventional variety. Therefore, based on the resistance of hybrid millets to the ACCase herbicides, SEY is used for weed control for hybrid foxtail millet crops in China (Wang et al. 2000, Xie et al. 2014). Nevertheless, different species and cultivars differ in their sensitivities to herbicide; in particular, foxtail millet is sensitive to herbicide at the seedling stage.

It is known that resistance towards herbicides can be caused by either alteration of the target site (TS), or nontarget site (NTS) mechanisms. Although molecular mechanisms of herbicides action are not yet completely understood even for some commercially available herbicides, about $60 \%$ of conventional herbicides interfere with the photosynthetic electron transport system of the chloroplast (Wakabayashi et al. 2004). Most research work focuses on the responses of the photosynthetic apparatus, while photosynthesis tolerance to SEY of non-target plants has not been elucidated yet. Previous research has shown that SEY is being widely used for Gramineae weeds control in Zhangza 5, with minimal damage up to

\section{Materials and methods}

Plants and experimental design: Foxtail millet (Setaria italica L.) cultivars, i.e., Zhangza 3, Zhangza 5, Zhangza 10 , and Jingu 21 , were used in the experiment. The hybrid foxtail millet varieties were supplied by Zhangjiakou Academy of Agricultural Sciences of Hebei Province, China, and the Jingu 21 was provided by Shanxi Academy of Agricultural Sciences, China. Sethoxydim (12.5\%, EC) was provided by Zhongnong Lihua Agricultural Chemical Products Co., Ltd., Tianjin, China.

The experiments were conducted in Shanxi Agricultural University, China and designed in a split-plot with three replicates (each replicate containing five pots), with varieties in the main plots and herbicide dosages in the sub-plots. Twenty foxtail millet seeds were sown in a plastic pot of $130 \mathrm{~mm}$ diameter, filled with a 1:2 mixture of sand and loam soil. The soil was a calcareous cinnamon soil, with $\mathrm{pH} 8.12,49.18 \mathrm{~g}$ (organic matter) $\mathrm{kg}^{-1}, 72.51$ mg(total nitrogen) $\mathrm{kg}^{-1}, 19.1 \mathrm{mg}$ (available phosphorus) $\mathrm{kg}^{-1}$, and $111.25 \mathrm{mg}$ (rapidly-available potassium) $\mathrm{kg}^{-1}$. The seeds were covered with $1 \mathrm{~cm}$ of sand:soil $(1: 2)$ mixture and each pot was carefully watered (under natural light, temperature of $28 / 16 \pm 3^{\circ} \mathrm{C}$ ). After emergence, the foxtail millet seedlings were thinned to 10 uniform plants per pot at the three-leaf stage.
$120 \mathrm{ml} \mathrm{L}^{-1}$ dosage of SEY (volume fraction). However, SEY dosage of $60 \mathrm{ml} \mathrm{L}^{-1}$ caused severe phytotoxicity in Jingu 21 (Xie et al. 2014). Thus, it is essential to understand the mechanisms involved in tolerance to SEYmediated photo-oxidative stress in non-target organisms.

Herbicides are effective for controlling their specific targeted weeds (Opeña et al. 2014), however, certain damage to the crop can also be caused by the herbicides, such as changes in their photochemistry and oxidative damage (Moustakas et al. 2016). Therefore, it is essential to study the effect of herbicides on the crop photosynthetic apparatus and reveal possible protection mechanisms of crop to herbicide exposure. Currently, there is little knowledge about the effect of the post-emergence herbicide SEY on photochemical changes and oxidative damage in the foxtail millet crops. Previous experiments have demonstrated a wide applicability of chlorophyll (Chl) fluorescence in research of plant responses to various stresses (including herbicides) (Kocurek et al. 2009, Kopsell et al. 2011, Tan et al. 2012). In particular, the technique of $\mathrm{Chl}$ fluorescence has been demonstrated as a very useful tool for estimating the effects of photosynthesis inhibitors in leaves without displaying any visual signs of damage (Hjorth et al. 2006, Wang et al. 2011).

The aim of this study was to examine the influence of SEY on photosynthesis and oxidative damage parameters, which could reveal if any photoprotective mechanisms exist in four types of foxtail millet. The results can provide evidence for the underlying mechanism of non-target plants after SEY exposure.

Five different dosages $[0,0.75,1.5,3$, and 6 L(SEY ai) $\mathrm{ha}^{-1}$ ] were applied using a laboratory pot-sprayer equipped with a nozzle, previously calibrated to deliver $450 \mathrm{~L} \mathrm{ha}^{-1}$, on foxtail millet seedlings at the five-leaf stage (most weeds grown at the three-leaf stage). The manufacturer recommended an effective dosage of $1.5 \mathrm{~L}(\mathrm{ai}) \mathrm{ha}^{-1}$ for field application. Except for the Jingu 21, physiological indexes of all the foxtail millet seedlings were analyzed after herbicide treatment for 7 and $15 \mathrm{~d}$. Jingu 21 seedlings treated with herbicide wilted or died after $15 \mathrm{~d}$ of the herbicide treatment, thus, only the data after $7 \mathrm{~d}$ of herbicide treatment was analyzed.

Photosynthetic pigments: Pigment contents of the leaves were evaluated according to the method proposed by Lichtenthaler (1987). After the exposure of foxtail millet seedlings to SEY, the fresh leaves of plants $(0.1 \mathrm{~g})$ were soaked in $10 \mathrm{~mL}$ of alcohol $(96 \%, \mathrm{v} / \mathrm{v})$ and stored in the dark for $24 \mathrm{~h}$. The supernatants were collected in order to measure the pigment contents. The absorbance of supernatants was measured at 649 and $665 \mathrm{~nm}$, by a $756 C-U V$ VIS spectrophotometer (Shanghai Spectrum Instruments Co., Ltd., China). The quantities of Chl $a$ and Chl $b$ were calculated using the following equations, respectively: 
Chl $a=13.95 \times \mathrm{OD}_{665}-6.88 \times \mathrm{OD}_{649}$

$\mathrm{Chl} b=24.96 \times \mathrm{OD}_{649}-7.32 \times \mathrm{OD}_{665}$

Malondialdehyde (MDA) was determined according to the method of Heath and Packer (1968). The leaves of the plants $(0.1 \mathrm{~g})$ were homogenized in an ice bath with $5 \mathrm{ml}$ of $0.1 \%$ trichloroacetic acid (TCA), and then mixed with $5 \mathrm{ml}$ of $0.5 \%$ thiobarbituric acid (TBA). The reaction mixture was boiled for $15 \mathrm{~min}$, cooled quickly, and centrifuged for $10 \mathrm{~min}$ at $4,000 \mathrm{rpm}$. The supernatant was used for measuring MDA concentration. Absorbance of the supernatant was measured by subtracting the nonspecific absorbance at $600 \mathrm{~nm}$ from the absorbance at $532 \mathrm{~nm}$, on a 756C-UV-VIS spectrophotometer (Shanghai Spectrum Instruments Co., Ltd., China). MDA concentration was calculated using an extinction coefficient of $155 \mathrm{mmol} \mathrm{L}^{-1} \mathrm{~cm}^{-1}$.

Superoxide generation rate was determined following the procedure described by Elstner and Heupel (1976). Leaf tissues $(0.1 \mathrm{~g})$ were homogenized with $2 \mathrm{ml}$ of 65 mmol L ${ }^{-1}$ Na-phosphate buffer ( $\left.\mathrm{pH} 7.8\right)$. The homogenate was centrifuged at $10,000 \mathrm{rpm}$ for $10 \mathrm{~min}$. The supernatant was collected to determine the superoxide production rate. Supernatant $(1 \mathrm{ml})$ was mixed with $1 \mathrm{ml}$ of $65 \mathrm{mmol} \mathrm{L}^{-1}$ Na-phosphate buffer (pH 7.8) and $0.2 \mathrm{ml}$ of $10 \mathrm{mmol} \mathrm{L}^{-1}$ hydroxylammonium chloride. After incubation for $20 \mathrm{~min}$ at $25^{\circ} \mathrm{C}, 1 \mathrm{ml}$ of the above reaction mixture was added to $1 \mathrm{ml}$ of $17 \mathrm{mmol} \mathrm{L}^{-1} 4$-aminobenzene sulfonic acid and 1 $\mathrm{ml}$ of $7 \mathrm{mmol} \mathrm{L}{ }^{-1} \alpha$-naphthylamine, mixed, and incubated for $30 \mathrm{~min}$ at $30^{\circ} \mathrm{C}$. The absorbance of the light pinkcolored aqueous phase was monitored at $530 \mathrm{~nm}$, on a 756C-UV-VIS spectrophotometer (Shanghai Spectrum Instruments Co., Ltd., China).

$\mathrm{H}_{2} \mathrm{O}_{2}$ content was determined according to the method of Zhang et al (2012). Leaf tissues (0.1g) were homogenized in an ice bath with $5 \mathrm{ml}$ of chilled acetone. The homogenate was centrifuged at 4,000 rpm for $15 \mathrm{~min}$ and $1 \mathrm{ml}$ of supernatant was added to $0.1 \mathrm{ml}$ of $20 \% \mathrm{TiCl}_{4}$ concentrated hydrochloric acid and $0.2 \mathrm{ml}$ of concentrated ammonium hydroxide. The mixture was centrifuged for $10 \mathrm{~min}$ at $10,000 \mathrm{rpm}$. The precipitate was dissolved in $3 \mathrm{~mL}$ of $1 \mathrm{~mol} \mathrm{~L}^{-1} \mathrm{H}_{2} \mathrm{SO}_{4}$. The absorbance of the supernatant was measured at $410 \mathrm{~nm}$ by a $756 C-U V$-VIS spectrophotometer (Shanghai Spectrum Instruments Co., Ltd., China).

Chl fluorescence and $\mathbf{P}_{700}$ parameters of foxtail millet were measured simultaneously on a Dual PAM-100 instrument (WALZ, Germany), using the automated Induction and Recovery Curve routine provided by the Dual PAM software (Pfündel et al. 2008). Prior to measurements, all the samples were kept in the dark for 30 min for dark adaptation. The fluorescence induced curve (slow kinetics) was measured according to the "Fluo $+\mathrm{P}_{700}$ " Analysis
Mode. Then, the kinetics of Chl fluorescence induction and $\mathrm{P}_{700}$ oxidation were recorded simultaneously by the instrument.

Firstly, the minimal fluorescence $\left(\mathrm{F}_{0}\right)$ was established and subsequently the maximum fluorescence $\left(\mathrm{F}_{\mathrm{m}}\right)$ was assessed using the "saturation pulse" method. Secondly, the maximal $\mathrm{P}_{700}$ change $\left(\mathrm{P}_{\mathrm{m}}\right)$ was measured by application of a saturation pulse (SP) $\left[4,000 \mu \mathrm{mol}\right.$ (photon) $\mathrm{m}^{-2} \mathrm{~s}^{-1}$, $800 \mathrm{~ms}$ ] after far-red pre-illumination. Thirdly, actinic illumination [130 $\mu \mathrm{mol}$ (photon) $\mathrm{m}^{-2} \mathrm{~s}^{-1}$ ] was started and SP was applied every $20 \mathrm{~s}$, with the same pulses serving for fluorescence and $\mathrm{P}_{700}$ analysis.

Maximum PSII quantum yield $\left(\mathrm{F}_{\mathrm{v}} / \mathrm{F}_{\mathrm{m}}\right)$ was calculated as $\mathrm{F}_{\mathrm{v}} / \mathrm{F}_{\mathrm{m}}=\left(\mathrm{F}_{\mathrm{m}}-\mathrm{F}_{0}\right) / \mathrm{F}_{\mathrm{m}}$. Other PSII energy dissipation parameters were determined by the Dual PAM software. Photochemical quenching, $\mathrm{q}_{\mathrm{p}}=\left(\mathrm{F}_{\mathrm{m}}{ }^{\prime}-\mathrm{F}\right) /\left(\mathrm{F}_{\mathrm{m}}{ }^{\prime}-\mathrm{F}_{0}{ }^{\prime}\right)$ was usually used as an indicator to reflect the redox level of the primary quinone electron acceptor of PSII $\left(\mathrm{Q}_{\mathrm{A}}\right)$. Apparent electron transfer efficiency (ETR) in PSII under illumination was calculated according to $\mathrm{ETR}_{\mathrm{II}}=\mathrm{PAR} \times 0.84 \times$ $0.5 \times \mathrm{Y}_{\mathrm{II}}$, and was used to measure electron transfer of carbon fixation resulting from photochemical reactions. Three complementary quantum yields of energy conversion in PSII were calculated according to the method described by Kramer et al. (2004): the effective PSII quantum yield $\left(\mathrm{Y}_{\mathrm{II}}\right)$ was calculated according to $\mathrm{Y}_{\mathrm{II}}=$ $\left(F_{m}\right.$ ' $\left.-F\right) / F_{m}$, the quantum yield of nonregulated energy dissipation in PSII was calculated by the equation $\mathrm{Y}_{\mathrm{NO}}=$ $1 /\left(\mathrm{NPQ}+1+\mathrm{q}_{\mathrm{L}}\left(\mathrm{F}_{\mathrm{m}} / \mathrm{F}_{0}-1\right)\right), \mathrm{NPQ}=\mathrm{F}_{\mathrm{m}} / \mathrm{F}_{\mathrm{m}}$ ' -1 , and the quantum yield of regulated energy dissipation in PSII was determined using the equation $\mathrm{Y}_{\mathrm{NPQ}}=1-\mathrm{Y}_{\mathrm{II}}-\mathrm{Y}_{\mathrm{NO}}$.

$\mathrm{P}_{700}$ oxidation was monitored by the difference be tween the $875 \mathrm{~nm}$ and $830 \mathrm{~nm}$ transmittance signals (Klughammer et al. 2008). The maximal change of the $\mathrm{P}_{700}$ signal reduced to fully oxidized state was denoted by $\mathrm{P}_{\mathrm{m}}$. $\mathrm{Y}_{\mathrm{NA}}$, the nonphotochemical quantum yield of PSI, was a measure of acceptor side limitation, and was calculated according to: $\mathrm{Y}_{\mathrm{NA}}=\left(\mathrm{P}_{\mathrm{m}}{ }^{\prime}-\mathrm{P}_{\mathrm{m}}\right) / \mathrm{P}_{\mathrm{m}}$ '. $\mathrm{Y}_{\mathrm{I}}$, photochemical quantum yield of PSI, was calculated according to $\mathrm{Y}_{\mathrm{I}}=$ $\left(\mathrm{P}_{\mathrm{m}}{ }^{\prime}-\mathrm{P}\right) / \mathrm{P}_{\mathrm{m}}$. $\mathrm{Y}_{\mathrm{ND}}$, the nonphotochemical quantum yield of PSI, was a measure of donor side limitation, and was calculated as $\mathrm{Y}_{\mathrm{ND}}=\left(\mathrm{P}-\mathrm{P}_{0}\right) / \mathrm{P}_{\mathrm{m}}$. The total value of the three quantum yields was one, i.e.: $\mathrm{Y}_{\mathrm{I}}+\mathrm{Y}_{\mathrm{ND}}+\mathrm{Y}_{\mathrm{NA}}=1$. The electron transfer efficiency of PSI as ETR $\mathrm{ET}_{\mathrm{I}}$ was assessed by the Dual PAM software.

Statistical analysis: The data (mean $\pm \mathrm{SE}$ ) were analyzed using the data processing system (SAS 8.0) program package according to a two-factor randomized complete block design to compare different herbicide dosages and different varieties. All the other data were subjected to the split-plot design analysis of variance (ANOVA), and Duncan's test $(P<0.05)$ was used to determine the significant differences between the treatments. 


\section{Results}

Plant height: The hybrid millet growth was significantly inhibited after $7 \mathrm{~d}$ of exposure to $1.5,3$, and $6 \mathrm{~L}$ (ai) ha $\mathrm{ha}^{-1}$ (Table 1). Similarly, treatment of Zhangza 10 with 1.5 to $6 \mathrm{~L}$ (ai) $\mathrm{ha}^{-1}$ resulted in a significant dose-dependent decrease in growth after $15 \mathrm{~d}$. However, the growth of Zhangza 3 and Zhangza 5 exposed to SEY for $15 \mathrm{~d}$ significantly decreased at $6 \mathrm{~L}$ (ai) $\mathrm{ha}^{-1}$, declining by 29.5 and $11.7 \%$, respectively. The growth of Jingu 21 was more affected than the hybrid millet and significant differences were found between the treatments (Fig. 1). The diminution of growth in Jingu 21 reached approximately
$4.1-10.4 \%$ after $7-\mathrm{d}$ exposure to $0.75-6 \mathrm{~L}$ (ai) $\mathrm{ha}^{-1}$, whereas the seedlings wilted or died after 15 -d exposure to herbicide.

MDA and ROS: The content of MDA and ROS showed a progressive increase with the increasing SEY concentrations (Table 2). Malondialdehyde (MDA) is a product of lipid peroxidation, and its content in Zhangza 3 significantly increased by 41.2 and $45.7 \%$ after $7 \mathrm{~d}$, and by 37.2 and $48.7 \%$ after 15 -d exposure to 3 and $6 \mathrm{~L}$ (ai) ha ${ }^{-1}$, respectively. A similar response was observed for MDA

Table 1. Effect of sethoxydim (SEY) on plant height in foxtail millet seedlings after 7-d or 15-d SEY exposure. Different letters in the same column represent significantly differences at $P<0.05$ level by Duncan's new multiple range test.

\begin{tabular}{|c|c|c|c|c|c|}
\hline Application [d] & SEY [L(ai) ha $\left.{ }^{-1}\right]$ & $\begin{array}{l}\text { Plant height }[\mathrm{cm}] \\
\text { Zhangzagu } 3\end{array}$ & Zhangzagu 5 & Zhangzagu 10 & Jingu 21 \\
\hline 7 & $\begin{array}{l}0 \\
0.75 \\
1.5 \\
3 \\
6\end{array}$ & $\begin{array}{l}35.53 \pm 1.42^{\mathrm{a}} \\
34.07 \pm 0.77^{\mathrm{ab}} \\
28.83 \pm 1.41^{\mathrm{bc}} \\
28.40 \pm 1.30^{\mathrm{c}} \\
28.17 \pm 2.14^{\mathrm{c}}\end{array}$ & $\begin{array}{l}30.80 \pm 0.40^{\mathrm{a}} \\
29.55 \pm 0.78^{\mathrm{ab}} \\
28.55 \pm 0.09^{\mathrm{bc}} \\
27.85 \pm 0.20^{\mathrm{c}} \\
27.60 \pm 0.29^{\mathrm{c}}\end{array}$ & $\begin{array}{l}30.43 \pm 0.90^{\mathrm{a}} \\
28.20 \pm 1.53^{\mathrm{ab}} \\
25.53 \pm 0.22^{\mathrm{bc}} \\
24.33 \pm 1.11^{\mathrm{c}} \\
20.70 \pm 1.49^{\mathrm{d}}\end{array}$ & $\begin{array}{l}28.40 \pm 0.40^{\mathrm{a}} \\
27.30 \pm 0.78^{\mathrm{b}} \\
26.05 \pm 0.09^{\mathrm{c}} \\
25.05 \pm 0.20^{\mathrm{d}} \\
22.00 \pm 0.29^{\mathrm{e}}\end{array}$ \\
\hline 15 & $\begin{array}{l}0 \\
0.75 \\
1.5 \\
3 \\
6\end{array}$ & $\begin{array}{l}40.03 \pm 3.66^{\mathrm{a}} \\
35.97 \pm 2.24^{\mathrm{a}} \\
34.30 \pm 0.72^{\mathrm{ab}} \\
34.20 \pm 1.23^{\mathrm{ab}} \\
28.23 \pm 1.47^{\mathrm{b}}\end{array}$ & $\begin{array}{l}34.10 \pm 0.40^{\mathrm{a}} \\
32.60 \pm 0.75^{\mathrm{ab}} \\
30.90 \pm 2.00^{\mathrm{ab}} \\
30.85 \pm 0.20^{\mathrm{ab}} \\
30.10 \pm 0.00^{\mathrm{b}}\end{array}$ & $\begin{array}{l}32.87 \pm 1.68^{\mathrm{a}} \\
29.20 \pm 1.01^{\mathrm{ab}} \\
26.50 \pm 0.21^{\mathrm{bc}} \\
25.40 \pm 2.33^{\mathrm{bc}} \\
21.67 \pm 1.61^{\mathrm{c}}\end{array}$ & \\
\hline
\end{tabular}
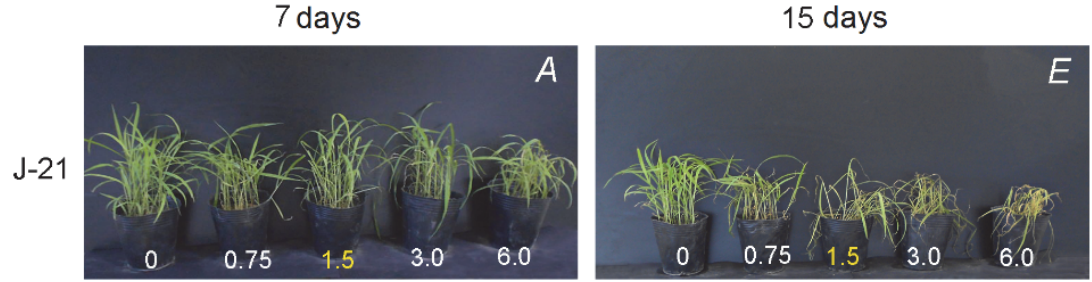

Z-3
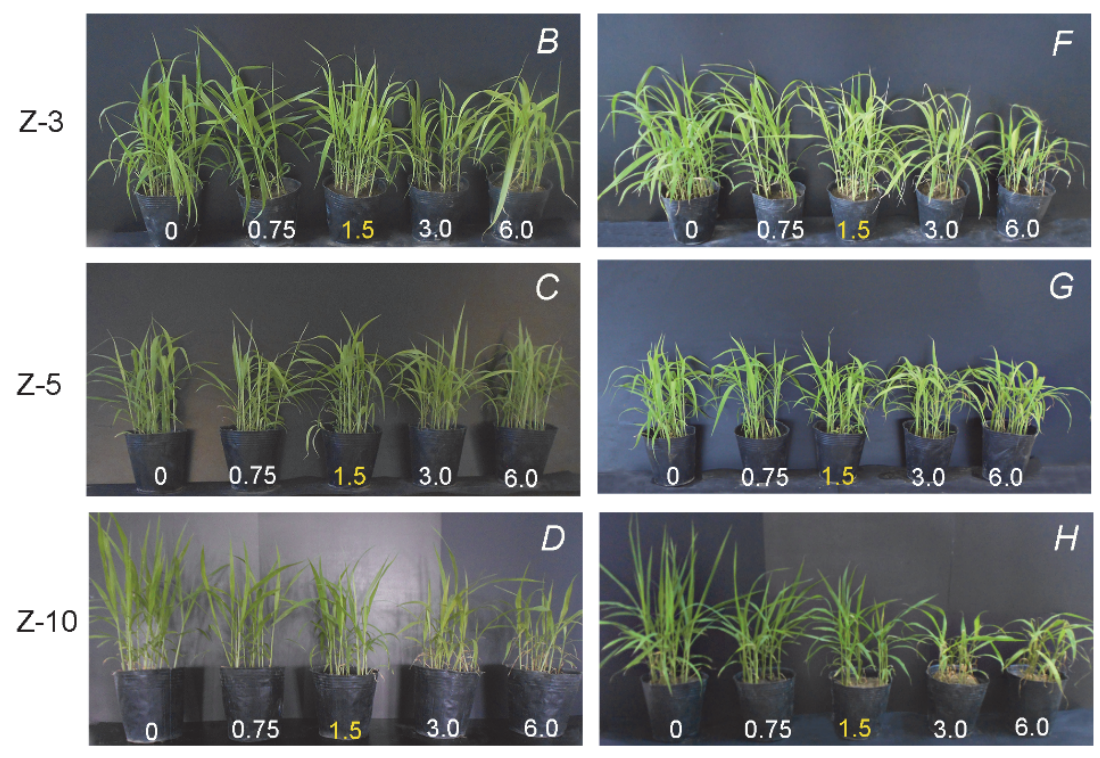

Fig. 1. Effect of increasing application rates of sethoxydim (SEY) on the survival. Representative photos of foxtail millet after $7 \mathrm{~d}$ or $15 \mathrm{~d}$ of SEY exposure. $A, E$ - Jingu 21; $B, F-$ Zhangza $3 ; C, G-$ Zhangza 5 ; $D, H$ - Zhangza 10 . 
Table 2. Effect of sethoxydim (SEY) on MDA/ROS leaves of foxtail millet seedlings after 7-d or 15-d SEY exposure. Different letters in the same column represent significantly differences at $P<0.05$ level by Duncan's new multiple range test. MDA - malondialdehyde content; FM - fresh mass; ROS - reactive oxygen species.

\begin{tabular}{|c|c|c|c|c|c|c|c|}
\hline \multirow[t]{2}{*}{ Variety } & \multirow[t]{2}{*}{ SEY $\left[\mathrm{L}(\mathrm{ai}) \mathrm{ha}^{-1}\right]$} & \multicolumn{2}{|c|}{ MDA $\left[\mathrm{nmol} \mathrm{g}^{-1}(\mathrm{FM})\right]$} & \multicolumn{2}{|c|}{$\begin{array}{l}\mathrm{O}_{2}^{-} \text {generating rate } \\
{\left[\mathrm{nmol} \mathrm{g}^{-1}(\mathrm{FM})\right]}\end{array}$} & \multicolumn{2}{|c|}{$\mathrm{H}_{2} \mathrm{O}_{2}\left[\mu \mathrm{mol} \mathrm{g}^{-1}(\mathrm{FM})\right]$} \\
\hline & & $7 \mathrm{~d}$ & $15 \mathrm{~d}$ & $7 \mathrm{~d}$ & $15 \mathrm{~d}$ & $7 \mathrm{~d}$ & $15 \mathrm{~d}$ \\
\hline Zhangzagu 3 & $\begin{array}{l}0 \\
0.75 \\
1.5 \\
3 \\
6\end{array}$ & $\begin{array}{l}1.13 \pm 0.00^{\mathrm{b}} \\
1.58 \pm 0.05^{\mathrm{ab}} \\
1.65 \pm 0.02^{\mathrm{ab}} \\
1.92 \pm 0.16^{\mathrm{a}} \\
2.08 \pm 0.36^{\mathrm{a}}\end{array}$ & $\begin{array}{l}1.15 \pm 0.20^{\mathrm{c}} \\
1.47 \pm 0.25^{\mathrm{bc}} \\
1.58 \pm 0.05^{\mathrm{bc}} \\
1.83 \pm 0.16^{\mathrm{ab}} \\
2.24 \pm 0.07^{\mathrm{a}}\end{array}$ & $\begin{array}{l}16.47 \pm 0.12^{\mathrm{b}} \\
16.70 \pm 0.54^{\mathrm{ab}} \\
17.15 \pm 0.00^{\mathrm{ab}} \\
17.62 \pm 0.24^{\mathrm{a}} \\
17.72 \pm 0.24^{\mathrm{a}}\end{array}$ & $\begin{array}{l}12.13 \pm 0.83^{\mathrm{b}} \\
17.64 \pm 0.07^{\mathrm{b}} \\
17.74 \pm 0.21^{\mathrm{b}} \\
18.45 \pm 0.02^{\mathrm{ab}} \\
19.61 \pm 0.47^{\mathrm{a}}\end{array}$ & $\begin{array}{l}6.09 \pm 0.00^{\mathrm{c}} \\
7.01 \pm 0.35^{\mathrm{c}} \\
9.31 \pm 0.26^{\mathrm{b}} \\
9.46 \pm 0.47^{\mathrm{b}} \\
16.28 \pm 0.04^{\mathrm{a}}\end{array}$ & $\begin{array}{l}6.36 \pm 1.57^{\mathrm{b}} \\
8.47 \pm 1.68^{\mathrm{ab}} \\
9.04 \pm 0.34^{\mathrm{ab}} \\
10.00 \pm 1.76^{\mathrm{ab}} \\
12.03 \pm 0.11^{\mathrm{a}}\end{array}$ \\
\hline Zhangzagu 5 & $\begin{array}{l}0 \\
0.75 \\
1.5 \\
3 \\
6\end{array}$ & $\begin{array}{l}1.29 \pm 0.02^{\mathrm{b}} \\
1.51 \pm 0.16^{\mathrm{b}} \\
1.58 \pm 0.14^{\mathrm{b}} \\
1.58 \pm 0.09^{\mathrm{b}} \\
2.39 \pm 0.14^{\mathrm{a}}\end{array}$ & $\begin{array}{l}1.45 \pm 0.31^{\mathrm{a}} \\
1.45 \pm 0.36^{\mathrm{a}} \\
1.49 \pm 0.36^{\mathrm{a}} \\
1.72 \pm 0.09^{\mathrm{a}} \\
1.83 \pm 0.11^{\mathrm{a}}\end{array}$ & $\begin{array}{l}15.76 \pm 0.34^{\mathrm{c}} \\
16.23 \pm 0.26^{\mathrm{bc}} \\
16.82 \pm 0.13^{\mathrm{b}} \\
16.94 \pm 0.26^{\mathrm{b}} \\
20.23 \pm 0.07^{\mathrm{a}}\end{array}$ & $\begin{array}{l}15.71 \pm 0.10^{\mathrm{c}} \\
15.90 \pm 0.07 \mathrm{~b}^{\mathrm{c}} \\
16.21 \pm 0.08^{\mathrm{ab}} \\
16.21 \pm 0.16^{\mathrm{ab}} \\
16.51 \pm 0.15^{\mathrm{a}}\end{array}$ & $\begin{array}{l}6.55 \pm 0.31^{\mathrm{c}} \\
7.59 \pm 0.07^{\mathrm{b}} \\
7.97 \pm 0.51^{\mathrm{b}} \\
9.43 \pm 0.03^{\mathrm{a}} \\
10.11 \pm 0.06^{\mathrm{a}}\end{array}$ & $\begin{array}{l}9.89 \pm 0.55^{\mathrm{b}} \\
10.57 \pm 0.07^{\mathrm{b}} \\
10.84 \pm 0.40^{\mathrm{ab}} \\
11.03 \pm 0.25^{\mathrm{ab}} \\
11.95 \pm 0.46^{\mathrm{a}}\end{array}$ \\
\hline Zhangzagu 10 & $\begin{array}{l}0 \\
0.75 \\
1.5 \\
3 \\
6\end{array}$ & $\begin{array}{l}1.57 \pm 0.02^{\mathrm{b}} \\
1.75 \pm 0.05^{\mathrm{ab}} \\
1.76 \pm 0.35^{\mathrm{ab}} \\
2.38 \pm 0.05^{\mathrm{a}} \\
2.42 \pm 0.10^{\mathrm{a}}\end{array}$ & $\begin{array}{l}1.57 \pm 0.18^{\mathrm{b}} \\
1.85 \pm 0.12^{\mathrm{ab}} \\
2.06 \pm 0.16^{\mathrm{ab}} \\
2.20 \pm 0.27^{\mathrm{ab}} \\
2.34 \pm 0.12^{\mathrm{a}}\end{array}$ & $\begin{array}{l}16.28 \pm 0.12^{\mathrm{b}} \\
17.25 \pm 0.52^{\mathrm{ab}} \\
18.05 \pm 0.28^{\mathrm{a}} \\
18.07 \pm 0.83^{\mathrm{a}} \\
18.07 \pm 0.07^{\mathrm{a}}\end{array}$ & $\begin{array}{l}16.68 \pm 0.08^{\mathrm{b}} \\
17.01 \pm 0.55^{\mathrm{b}} \\
17.06 \pm 0.23^{\mathrm{b}} \\
17.72 \pm 0.52^{\mathrm{b}} \\
19.07 \pm 0.01^{\mathrm{a}}\end{array}$ & $\begin{array}{l}3.53 \pm 0.02^{\mathrm{d}} \\
4.49 \pm 0.18^{\mathrm{b}} \\
5.37 \pm 0.11^{\mathrm{b}} \\
5.83 \pm 0.03^{\mathrm{b}} \\
8.32 \pm 0.34^{\mathrm{a}}\end{array}$ & $\begin{array}{l}3.03 \pm 0.99^{\mathrm{c}} \\
3.87 \pm 0.31^{\mathrm{bc}} \\
4.60 \pm 0.65^{\mathrm{abc}} \\
5.98 \pm 0.11^{\mathrm{ab}} \\
6.29 \pm 0.57^{\mathrm{a}}\end{array}$ \\
\hline Jingu 21 & $\begin{array}{l}0 \\
0.75 \\
1.5 \\
3 \\
6\end{array}$ & $\begin{array}{l}1.02 \pm 0.11^{\mathrm{b}} \\
1.87 \pm 0.29^{\mathrm{ab}} \\
2.10 \pm 0.47^{\mathrm{a}} \\
2.15 \pm 0.07^{\mathrm{a}} \\
2.24 \pm 0.20^{\mathrm{a}}\end{array}$ & & $\begin{array}{l}15.07 \pm 0.05^{\mathrm{c}} \\
15.97 \pm 0.16^{\mathrm{b}} \\
16.23 \pm 0.20^{\mathrm{ab}} \\
16.25 \pm 0.08^{\mathrm{ab}} \\
17.06 \pm 0.52^{\mathrm{a}}\end{array}$ & & $\begin{array}{l}7.17 \pm 0.27^{\mathrm{e}} \\
11.15 \pm 0.03^{\mathrm{d}} \\
11.57 \pm 0.12^{\mathrm{c}} \\
12.53 \pm 0.07^{\mathrm{b}} \\
16.89 \pm 0.05^{\mathrm{a}}\end{array}$ & \\
\hline
\end{tabular}

accumulation in Zhangza 10 exposed to SEY from 3 to 6 $\mathrm{L}(\mathrm{ai}) \mathrm{h}^{-1}$ for $7 \mathrm{~d}$, which was significantly higher than that of the control. However, the MDA content of Zhangza 10 significantly increased (49.0\%), following 15-d exposure to $6 \mathrm{~L}$ (ai) $\mathrm{ha}^{-1}$. MDA content in Zhangza 5 significantly increased by $40.0 \%$ after $7 \mathrm{~d}$ of treatment with $6 \mathrm{~L}(\mathrm{ai}) \mathrm{ha}^{-1}$, whereas no significant differences were found between the treatments after 15-d exposure. After exposure to SEY at 1.5-6 L(ai) ha ${ }^{-1}$ for $7 \mathrm{~d}$, the MDA content of Jingu 21 was significantly higher than that of the control.

ROS can act as an indicator of oxidative stress. The ROS contents increased with an increase in SEY concentrations (Table 2). The $\mathrm{O}_{2}$ - content of Zhangza 3 significantly increased by 6.5 and $7.1 \%$ after $7 \mathrm{~d}$ of 3 and $6 \mathrm{~L}$ (ai) $\mathrm{ha}^{-1}$, respectively, and the significant increase was found after treatment with $6 \mathrm{~L}$ (ai) $\mathrm{ha}^{-1}$ for $15 \mathrm{~d}$. SEY at $1.5-6$ $\mathrm{L}$ (ai) $\mathrm{ha}^{-1}$ significantly increased the $\mathrm{O}_{2}$ - content of Zhangza 5 after 7-d and 15-d exposure. Similarly, the $\mathrm{O}_{2}-$ content of Zhangza 10 was significantly higher than that of the control after $7 \mathrm{~d}$ with $1.5-6 \mathrm{~L}(\mathrm{ai}) \mathrm{ha}^{-1}$. The $\mathrm{O}_{2}$ - content of Zhangza 10 significantly increased following $15 \mathrm{~d}$ of exposure to $6 \mathrm{~L}$ (ai) $\mathrm{ha}^{-1}$. After $7 \mathrm{~d}$ of exposure to SEY at 1.5-6 L(ai) ha ${ }^{-1}$, the $\mathrm{H}_{2} \mathrm{O}_{2}$ content of Zhangza 3 showed the significant increase. Moreover, after $7 \mathrm{~d}$ of treatment, the $\mathrm{H}_{2} \mathrm{O}_{2}$ content of Zhangza 5 and Zhangza 10 showed similar trends, which revealed significant differences in plants exposed to SEY from 0.75 to $6 \mathrm{~L}$ (ai) ha $\mathrm{ha}^{-1}$ compared with the control. Additionally, SEY at $6 \mathrm{~L}$ (ai) ha ${ }^{-1}$ also significantly increased the $\mathrm{H}_{2} \mathrm{O}_{2}$ content in both Zhangza 3 and Zhangza 5 after $15 \mathrm{~d}$ of exposure. After $15 \mathrm{~d}$ of 3 and $6 \mathrm{~L}$ (ai) ha ${ }^{-1}$ SEY treatment, the $\mathrm{H}_{2} \mathrm{O}_{2}$ content of Zhangza 10 increased by 49.3 and $51.8 \%$, respectively. Furthermore, after $7 \mathrm{~d}$ of treatment, the $\mathrm{O}_{2}$ - and $\mathrm{H}_{2} \mathrm{O}_{2}$ content of Jingu 21 in the SEY-treated plants increased more significantly, which revealed significant differences in plants exposed to SEY from 0.75 to $6 \mathrm{~L}$ (ai) ha $\mathrm{ha}^{-1}$ compared with the control.

Photosynthetic pigments: Total $\mathrm{Chl}, \mathrm{Chl} a, \mathrm{Chl} b$, and $\mathrm{Chl} a / b$ in leaves of foxtail millet declined with increasing SEY concentrations (Table 3). Although both the hybrid millet and Jingu 21 showed similar trends, the decreasing pigment contents in each variety were not identical. Compared to Jingu $21, \mathrm{Chl} a / b$ of the hybrid millet were not significant between each SEY treatment after $15 \mathrm{~d}$ of SEY exposure. After 7-d and 15-d exposure to 0.75$6 \mathrm{~L}$ (ai) ha ${ }^{-1}$, total $\mathrm{Chl}, \mathrm{Chl} a$, and $\mathrm{Chl} b$ were significantly lower than those of the control in Zhangza 3 and Jingu 21. Moreover, the total Chl, Chl $a$, and Chl $b$ of Zhangza 5 showed a similar trend, in which significant differences were found after $7 \mathrm{~d}$ and $15 \mathrm{~d}$ of exposure to SEY at 1.5 to $6 \mathrm{~L}$ (ai) ha ${ }^{-1}$. However, SEY at 3 and $6 \mathrm{~L}$ (ai) ha ${ }^{-1}$ significantly decreased total $\mathrm{Chl}$ by more than $50 \%$ and $\mathrm{Chl} a$ by more than $60 \%$ after $7 \mathrm{~d}$ of exposure. The total Chl, Chl $a$, and $\mathrm{Chl} b$ of Zhangza 10 significantly decreased from 0.75 to $6 \mathrm{~L}$ (ai) ha $\mathrm{ha}^{-1}$ after $15 \mathrm{~d}$ of SEY exposure. 
Table 3. Effect of sethoxydim (SEY) on the photosynthetic pigment content in leaves of foxtail millet seedlings after 7-d or 15-d SEY exposure. Different letters in the same column represent significantly differences at $P<0.05$ level by Duncan's new multiple range test. $\mathrm{Chl}$ - chlorophyll; FM - fresh mass.

\begin{tabular}{|c|c|c|c|c|c|c|}
\hline Varieties & Application [d] & SEY [L(ai) ha $\left.{ }^{-1}\right]$ & $\mathrm{Chl}\left[\mathrm{mg} \mathrm{g}^{-1}(\mathrm{FM})\right]$ & Chl $a\left[\mathrm{mg} \mathrm{g}^{-1}(\mathrm{FM})\right]$ & Chl $b\left[\mathrm{mg} \mathrm{g}^{-1}(\mathrm{FM})\right]$ & Chl $a / b$ \\
\hline Zhangzagu 3 & 15 & $\begin{array}{l}0 \\
0.75 \\
1.5 \\
3 \\
6 \\
0 \\
0.75 \\
1.5 \\
3 \\
6\end{array}$ & $\begin{aligned} 7.03 & \pm 0.16^{\mathrm{a}} \\
6.26 & \pm 0.12^{\mathrm{b}} \\
4.29 & \pm 0.08^{\mathrm{c}} \\
4.24 & \pm 0.01^{\mathrm{c}} \\
2.57 & \pm 0.09^{\mathrm{d}} \\
16.77 & \pm 0.31^{\mathrm{a}} \\
13.52 & \pm 0.13^{\mathrm{b}} \\
12.48 & \pm 0.20^{\mathrm{c}} \\
10.49 & \pm 0.13^{\mathrm{d}} \\
8.38 & \pm 0.27^{\mathrm{e}}\end{aligned}$ & $\begin{aligned} 5.94 & \pm 0.09^{\mathrm{a}} \\
5.34 & \pm 0.13^{\mathrm{b}} \\
3.67 & \pm 0.07^{\mathrm{c}} \\
3.53 & \pm 0.29^{\mathrm{c}} \\
2.47 & \pm 0.07^{\mathrm{d}} \\
12.69 & \pm 0.08^{\mathrm{a}} \\
10.28 & \pm 0.08^{\mathrm{b}} \\
9.44 & \pm 0.55^{\mathrm{b}} \\
7.88 & \pm 0.38^{\mathrm{c}} \\
6.32 & \pm 0.20^{\mathrm{d}}\end{aligned}$ & $\begin{array}{l}1.09 \pm 0.01^{\mathrm{a}} \\
0.93 \pm 0.04^{\mathrm{b}} \\
0.61 \pm 0.01^{\mathrm{d}} \\
0.71 \pm 0.05^{\mathrm{c}} \\
0.11 \pm 0.00^{\mathrm{e}} \\
4.08 \pm 0.00^{\mathrm{a}} \\
3.24 \pm 0.02^{\mathrm{b}} \\
3.04 \pm 0.01^{\mathrm{c}} \\
2.61 \pm 0.03^{\mathrm{d}} \\
2.07 \pm 0.04^{\mathrm{e}}\end{array}$ & $\begin{array}{l}5.45 \pm 0.14^{\mathrm{b}} \\
5.76 \pm 0.23^{\mathrm{b}} \\
5.99 \pm 0.04^{\mathrm{b}} \\
4.95 \pm 0.42^{\mathrm{b}} \\
3.23 \pm 0.95^{\mathrm{a}} \\
3.11 \pm 0.02^{\mathrm{a}} \\
3.17 \pm 0.01^{\mathrm{a}} \\
3.11 \pm 0.19^{\mathrm{a}} \\
3.02 \pm 0.11^{\mathrm{a}} \\
3.06 \pm 0.16^{\mathrm{a}}\end{array}$ \\
\hline Zhangzagu 5 & 15 & $\begin{array}{l}0 \\
0.75 \\
1.5 \\
3 \\
6 \\
0 \\
0.75 \\
1.5 \\
3 \\
6\end{array}$ & $\begin{aligned} 9.81 & \pm 0.20^{\mathrm{a}} \\
9.57 & \pm 0.02^{\mathrm{a}} \\
7.73 & \pm 0.38^{\mathrm{b}} \\
7.28 & \pm 0.09^{\mathrm{b}} \\
7.02 & \pm 0.29^{\mathrm{b}} \\
13.35 & \pm 0.04^{\mathrm{a}} \\
13.32 & \pm 0.21^{\mathrm{a}} \\
11.13 & \pm 0.29^{\mathrm{b}} \\
9.70 & \pm 0.30^{\mathrm{c}} \\
9.54 & \pm 0.14^{\mathrm{c}}\end{aligned}$ & $\begin{aligned} 7.78 & \pm 0.18^{\mathrm{a}} \\
7.40 & \pm 0.24^{\mathrm{a}} \\
5.98 & \pm 0.03^{\mathrm{b}} \\
5.80 & \pm 0.38^{\mathrm{b}} \\
5.42 & \pm 0.23^{\mathrm{b}} \\
10.78 & \pm 0.40^{\mathrm{a}} \\
10.71 & \pm 0.05^{\mathrm{a}} \\
8.97 & \pm 0.24^{\mathrm{b}} \\
7.68 & \pm 0.23^{\mathrm{c}} \\
7.65 & \pm 0.02^{\mathrm{c}}\end{aligned}$ & $\begin{array}{l}2.02 \pm 0.02^{\mathrm{a}} \\
2.17 \pm 0.07^{\mathrm{a}} \\
1.75 \pm 0.07^{\mathrm{b}} \\
1.49 \pm 0.01^{\mathrm{c}} \\
1.60 \pm 0.01^{\mathrm{bc}} \\
2.54 \pm 0.02^{\mathrm{a}} \\
2.61 \pm 0.04^{\mathrm{a}} \\
2.16 \pm 0.01^{\mathrm{b}} \\
2.03 \pm 0.01^{\mathrm{c}} \\
1.89 \pm 0.04^{\mathrm{d}}\end{array}$ & $\begin{array}{l}3.85 \pm 0.06^{\mathrm{ab}} \\
3.42 \pm 0.01^{\mathrm{bc}} \\
3.43 \pm 0.12^{\mathrm{bc}} \\
3.90 \pm 0.28^{\mathrm{a}} \\
3.39 \pm 0.13^{\mathrm{c}} \\
4.25 \pm 0.13^{\mathrm{a}} \\
4.10 \pm 0.04^{\mathrm{ab}} \\
4.15 \pm 0.12^{\mathrm{ab}} \\
3.79 \pm 0.09^{\mathrm{b}} \\
4.05 \pm 0.10^{\mathrm{ab}}\end{array}$ \\
\hline Zhangzagu 10 & 15 & $\begin{array}{l}0 \\
0.75 \\
1.5 \\
3 \\
6 \\
0 \\
0.75 \\
1.5 \\
3 \\
6\end{array}$ & $\begin{aligned} 12.71 & \pm 0.29^{\mathrm{a}} \\
12.65 & \pm 0.77^{\mathrm{a}} \\
12.36 & \pm 0.04^{\mathrm{a}} \\
5.23 & \pm 0.02^{\mathrm{b}} \\
3.58 & \pm 0.20^{\mathrm{c}} \\
17.78 & \pm 0.05^{\mathrm{a}} \\
12.66 & \pm 0.36^{\mathrm{b}} \\
10.65 & \pm 0.61^{\mathrm{c}} \\
10.02 & \pm 0.51^{\mathrm{c}} \\
7.11 & \pm 0.10^{\mathrm{d}}\end{aligned}$ & $\begin{aligned} 9.83 & \pm 0.01^{\mathrm{a}} \\
10.00 & \pm 0.04^{\mathrm{a}} \\
9.54 & \pm 0.57^{\mathrm{a}} \\
3.77 & \pm 0.15^{\mathrm{b}} \\
2.62 & \pm 0.19^{\mathrm{c}} \\
13.86 & \pm 0.35^{\mathrm{a}} \\
9.85 & \pm 0.07^{\mathrm{b}} \\
8.27 & \pm 0.09^{\mathrm{c}} \\
7.85 & \pm 0.25^{\mathrm{c}} \\
5.45 & \pm 0.10^{\mathrm{d}}\end{aligned}$ & $\begin{array}{l}2.88 \pm 0.04^{\mathrm{a}} \\
2.65 \pm 0.16^{\mathrm{a}} \\
2.82 \pm 0.03^{\mathrm{a}} \\
1.46 \pm 0.12^{\mathrm{b}} \\
0.96 \pm 0.02^{\mathrm{c}} \\
3.93 \pm 0.01^{\mathrm{a}} \\
2.80 \pm 0.07^{\mathrm{b}} \\
2.39 \pm 0.01^{\mathrm{c}} \\
2.17 \pm 0.09^{\mathrm{d}} \\
1.67 \pm 0.03^{\mathrm{e}}\end{array}$ & $\begin{array}{l}3.41 \pm 0.05^{\mathrm{b}} \\
3.77 \pm 0.03^{\mathrm{a}} \\
3.39 \pm 0.25^{\mathrm{b}} \\
2.58 \pm 0.10^{\mathrm{c}} \\
2.72 \pm 0.15^{\mathrm{c}} \\
3.53 \pm 0.08^{\mathrm{a}} \\
3.52 \pm 0.06^{\mathrm{a}} \\
3.46 \pm 0.05^{\mathrm{a}} \\
3.63 \pm 0.26^{\mathrm{a}} \\
3.27 \pm 0.13^{\mathrm{a}}\end{array}$ \\
\hline Jingu 21 & 7 & $\begin{array}{l}0 \\
0.75 \\
1.5 \\
3 \\
6\end{array}$ & $\begin{aligned} 13.16 & \pm 0.05^{\mathrm{a}} \\
9.14 & \pm 0.01^{\mathrm{b}} \\
8.93 & \pm 0.01^{\mathrm{b}} \\
8.68 & \pm 0.23^{\mathrm{b}} \\
7.29 & \pm 0.19^{\mathrm{c}}\end{aligned}$ & $\begin{array}{r}10.53 \pm 0.05^{\mathrm{a}} \\
7.28 \pm 0.27^{\mathrm{b}} \\
7.12 \pm 0.27^{\mathrm{b}} \\
6.76 \pm 0.02^{\mathrm{b}} \\
5.85 \pm 0.19^{\mathrm{c}}\end{array}$ & $\begin{array}{l}2.63 \pm 0.00^{\mathrm{a}} \\
1.86 \pm 0.04^{\mathrm{bc}} \\
1.82 \pm 0.03^{\mathrm{c}} \\
1.92 \pm 0.03^{\mathrm{b}} \\
1.45 \pm 0.01^{\mathrm{d}}\end{array}$ & $\begin{array}{l}4.01 \pm 0.02^{\mathrm{a}} \\
3.92 \pm 0.22^{\mathrm{a}} \\
3.92 \pm 0.23^{\mathrm{a}} \\
3.53 \pm 0.05^{\mathrm{b}} \\
4.03 \pm 0.12^{\mathrm{a}}\end{array}$ \\
\hline
\end{tabular}

Chl fluorescence parameters: The $\mathrm{F}_{\mathrm{v}} / \mathrm{F}_{\mathrm{m}}$ values of Jingu 21 significantly dropped after $7 \mathrm{~d}$ with $0.75,1.5,3$, and $6 \mathrm{~L}$ (ai) $\mathrm{ha}^{-1}$ (Fig. $2 A$ ). Moreover, after $7 \mathrm{~d}$ of treatment, SEY at 0.75 and $1.5 \mathrm{~L}$ (ai) ha ${ }^{-1}$ decreased the $\mathrm{F}_{\mathrm{v}} / \mathrm{F}_{\mathrm{m}}$ values in the hybrid millet, and then the $\mathrm{F}_{\mathrm{v}} / \mathrm{F}_{\mathrm{m}}$ values recovered to the control level after $15 \mathrm{~d}$ of the exposure (Fig. $2 B-D$ ). After exposure to SEY at $6 \mathrm{~L}$ (ai) $\mathrm{ha}^{-1}$, the $\mathrm{F}_{\mathrm{v}} / \mathrm{F}_{\mathrm{m}}$ values were significantly reduced (Table $1 \mathrm{~S}$, supplement available online). Additionally, after 15-d exposure to $6 \mathrm{~L}$ (ai) $\mathrm{ha}^{-1}$, the $F_{v} / F_{m}$ values showed some recovery, but the $F_{v} / F_{m}$ values of Zhangza 3 and Zhangza 10 were significantly lower than that of the control $(4.7$ and $12.6 \%$, respectively). $F_{v} / F_{0}$ also decreased with the increase in SEY dosages. For Zhangza 3, $F_{v} / F_{0}$ was slightly lower than that of the control after treatment with 0.75 and $1.5 \mathrm{~L}$ (ai) $\mathrm{ha}^{-1}$ at $7 \mathrm{~d}$, and significantly decreased after 7-d exposure to 3 and $6 \mathrm{~L}$ (ai) $\mathrm{ha}^{-1}$. However, there were no differences in
$\mathrm{F}_{\mathrm{v}} / \mathrm{F}_{0}$ between Zhangza 5 and Zhangza 10 after 7-d exposure to $0.75,1.5,3$, and $6 \mathrm{~L}$ (ai) ha ${ }^{-1}$. Furthermore, each SEY treatment of Jingu 21 caused significant inhibition of $\mathrm{F}_{\mathrm{v}} / \mathrm{F}_{0}$ after $7 \mathrm{~d}$ of exposure.

Changes of $Y_{\text {II }}, E_{\text {ETR }}$, and $\mathrm{qP}_{\mathrm{P}}$ under the SEY treatment were consistent and values decreased in a dose-dependent manner. $\mathrm{Y}_{\text {II }}$ was reduced by $39.8-81.3 \%$, ETR $\mathrm{EII}_{\text {II }}$ decreased by $39.9-81.2 \%$, and qp decreased by $55.9-94.70 \%$ in Jingu 21 (Figs. 2E, 3A, Table 1S). For the hybrid millet, the variation of $Y_{\text {II }}$ was similar to that of $E_{T R}$, which revealed significant differences in plants exposed to SEY from 0.75 to $6 \mathrm{~L}$ (ai) $\mathrm{ha}^{-1}$ compared with the control, respectively.

After $7 \mathrm{~d}$ of exposure to SEY, $\mathrm{Y}_{\text {No }}$ increased in Jingu 21, but there was not significant difference between the treatments (Fig. 3B). On one hand, compared to $\mathrm{Y}_{\mathrm{NO}}, \mathrm{Y}_{\mathrm{NPQ}}$ showed the opposite trend in Jingu 21. Additionally, SEY 


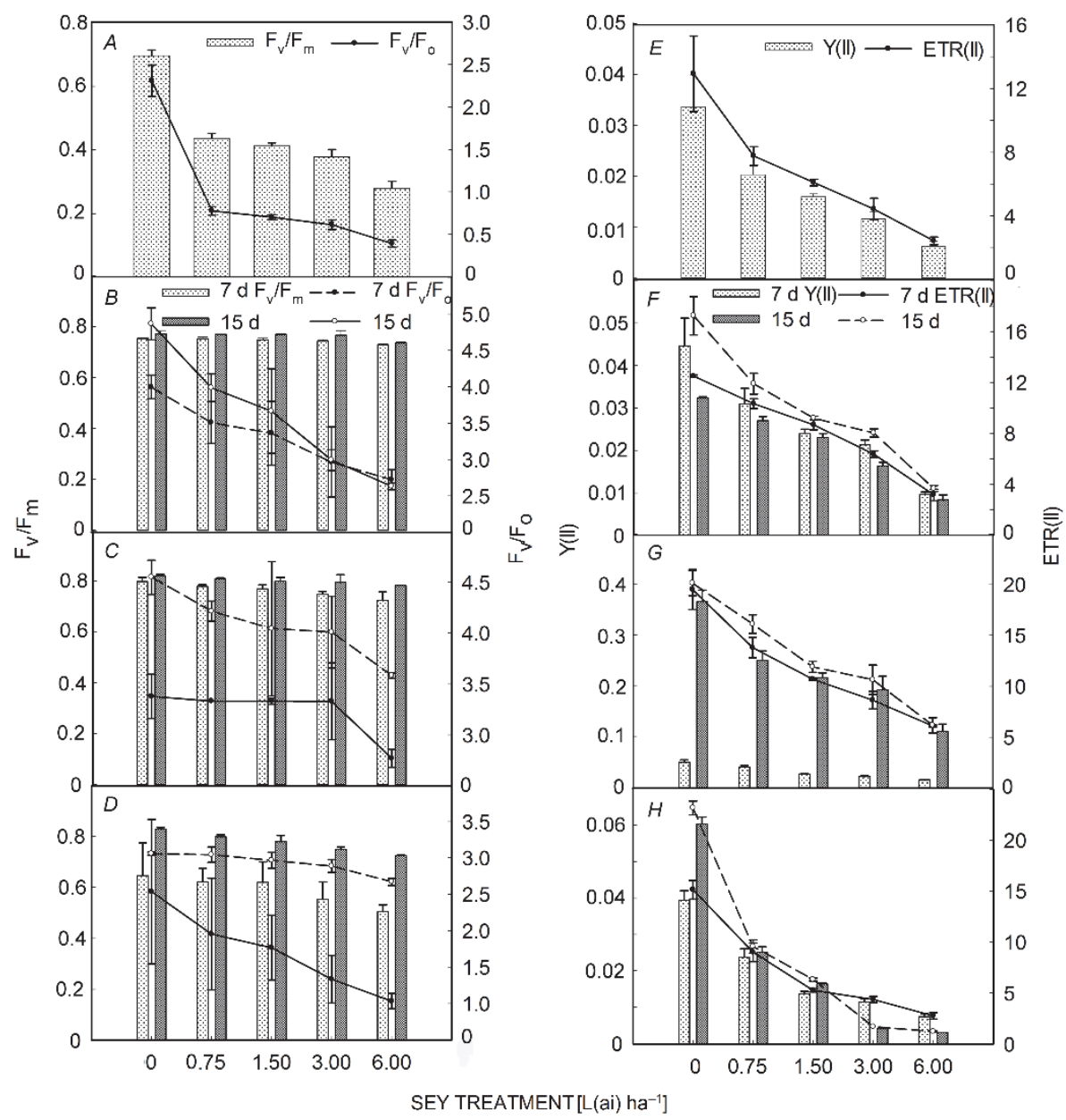

Fig. 2. Effect of sethoxydim (SEY) on PSII parameters in leaves of foxtail millet seedlings. PSII parameters of Jingu 21 were assessed after $7 \mathrm{~d}$ of exposure to SEY and PSII parameters of Zhangza 3, Zhangza 5, and Zhangza 10 were assessed after $7 \mathrm{~d}$ and $15 \mathrm{~d}$ of exposure to SEY. $\mathrm{F}_{\mathrm{v}} / \mathrm{F}_{\mathrm{m}}$ - maximum quantum yield of PS; $\mathrm{F}_{\mathrm{v}} / \mathrm{F}_{0}$ - potential activity of PSII; $\mathrm{Y}_{\mathrm{II}}-$ PSII effective quantum yield; ETR $\mathrm{II}-\mathrm{PSII}$ electron transport rate. $A, E$ - Jingu 21; $B, F$-Zhangza 3; $C, G$-Zhangza 5; $D, H$-Zhangza 10.

at $0.75 \mathrm{~L}$ (ai) ha $\mathrm{ha}^{-1}$ also significantly decreased $\mathrm{Y}_{\mathrm{NPQ}}$ for Zhangza 3 and Zhangza 10 after $7 \mathrm{~d}$ of exposure. On the other hand, there were no significant differences in $\mathrm{Y}_{\mathrm{NPQ}}$ for Zhangza 5 after 7-d exposure to $0.75,1.5,3$, and $6 \mathrm{~L}$ (ai) ha $^{-1}$ (Fig. 2G). Furthermore, after $15 \mathrm{~d}$ of exposure to $0.75 \mathrm{~L}$ (ai) $\mathrm{ha}^{-1}, \mathrm{Y}_{\mathrm{NO}}$ was significantly lower than the control, and decreased by $31.4,55.1$, and $7.5 \%$, respectively, for the hybrid millet Zhangza (Table 1S).

P $_{700}$ parameters: Increasing SEY dosages induced a decrease in $\mathrm{P}_{\mathrm{m}}, \mathrm{Y}_{\mathrm{I}}$, and $\mathrm{ETR}_{\mathrm{I}}$. $\mathrm{P}_{\mathrm{m}}$ was slightly lower than that of the control (Fig. $4 A-C, E-G$ ), but there were no significant differences in Jingu 21, Zhangza 3, and Zhangza 5 after $7 \mathrm{~d}$ of exposure, respectively. Moreover, SEY at $6 \mathrm{~L}$ (ai) ha $\mathrm{ha}^{-1}$ decreased $\mathrm{P}_{\mathrm{m}}$ by 51.5 and $39.7 \%$ in

\section{Discussion}

Previous studies have demonstrated that the effect of herbicides on crops may be revealed through morphological variations (plant height, leaf color, plant growth speed,
Zhangza 10 after $7 \mathrm{~d}$ and $15 \mathrm{~d}$ of exposure, respectively (Table 2S, supplement available online). Both $\mathrm{Y}_{\mathrm{I}}$ and ETR $\mathrm{R}_{\mathrm{I}}$ showed similar trends, i.e., treatment with SEY resulted in a dose-dependent decrease in Jingu 21 and the hybrid millet. $\mathrm{Y}_{\mathrm{NA}}$ increased with the increase in SEY dosage (Fig. 4I). Also, the SEY treatment resulted in the decrease of $\mathrm{Y}_{\mathrm{ND}}$ for Jingu 21, but no significant differences were observed between the different dosages (Table 2S). However, $\mathrm{Y}_{\mathrm{ND}}$ first increased and then decreased with the increase in SEY dosage after $7 \mathrm{~d}$ and $15 \mathrm{~d}$ of exposure in the hybrid millet (Fig. 4J,K,L). Additionally, after $7 \mathrm{~d}$ of exposure to $\mathrm{SEY}$ at $3 \mathrm{~L}$ (ai) $\mathrm{ha}^{-1}$, the $\mathrm{Y}_{\mathrm{NA}}$ and $\mathrm{Y}_{\mathrm{ND}}$ values were 57.7 and $82.6 \%$ of the control for Zhangza 5, respectively (Fig. $4 K$ ).

biomass, yield, etc.) and physiological changes [Chl content, photosynthesis (Wang et al. 2012), protective enzyme activities, lipid peroxidation (Zhao et al. 2010), etc.]. 

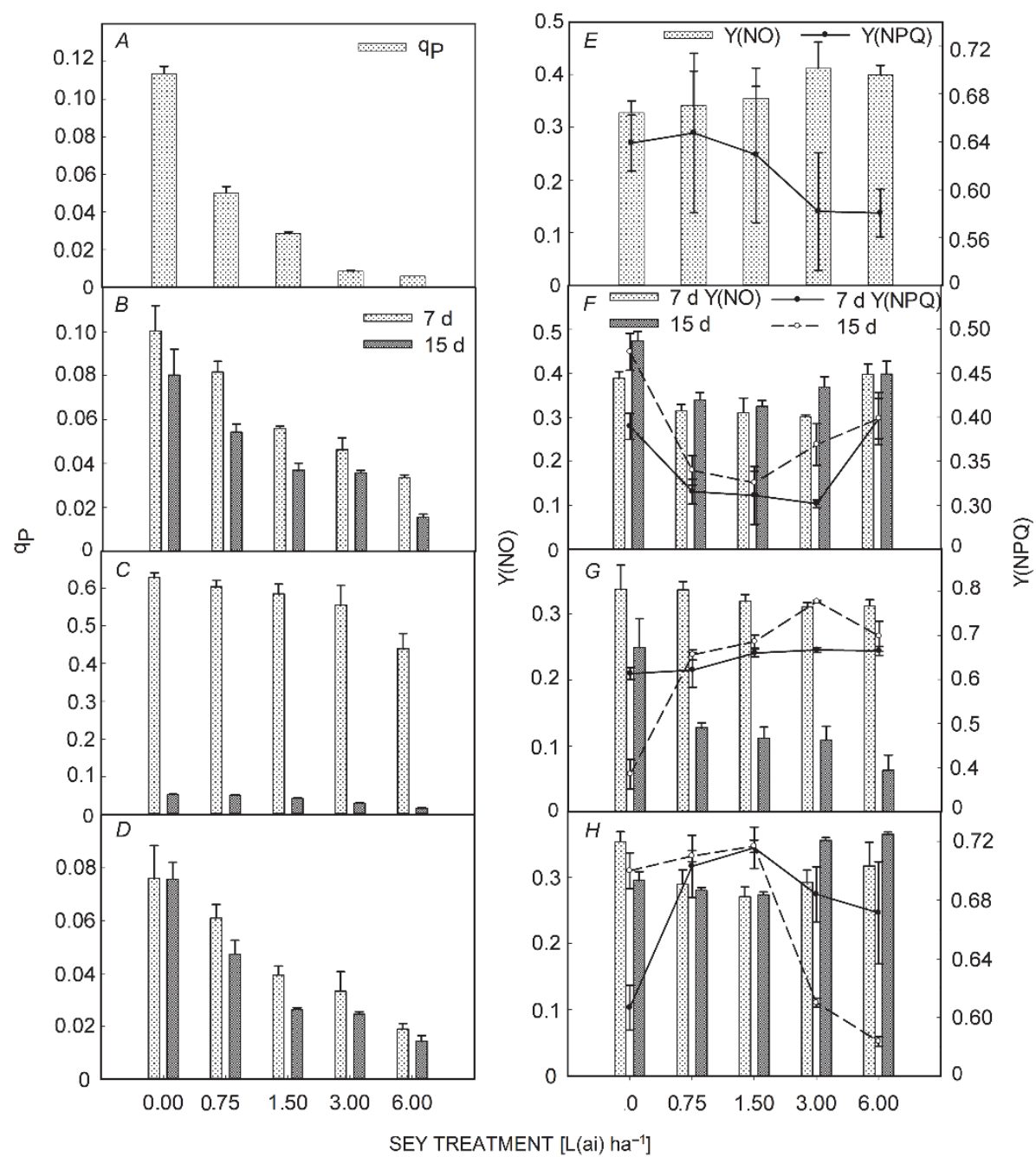

Fig. 3. Effect of sethoxydim (SEY) on PSII parameters in leaves of foxtail millet seedlings. PSII parameters of Jingu 21 were assessed after $7 \mathrm{~d}$ of exposure to SEY and PSII parameters of Zhangza 3, Zhangza 5, and Zhangza 10 were assessed after $7 \mathrm{~d}$ and $15 \mathrm{~d}$ of exposure to SEY. Y $Y_{\mathrm{NO}}$ - quantum yield of nonregulated energy dissipation in PSII; $Y_{\mathrm{NPQ}}$ - quantum yield of regulated energy dissipation in PSII; qP - photochemical quenching. $A, E$ - Jingu 21; $B, F$-Zhangza 3; $C, G$-Zhangza 5; $D, H$-Zhangza 10.

In this study, we found that SEY dosage $\geq 0.75 \mathrm{~L}$ (ai) $\mathrm{ha}^{-1}$ caused marked effects on the Jingu 21 seedlings and resulted in death after $15 \mathrm{~d}$. Moreover, the recommended dosage of SEY (1.5 $\mathrm{L} \mathrm{ha}^{-1}$ ) also caused slight inhibition in the growth of the hybrid millet (Zhangza) but seedlings could grow further. The reduction of seedlings growth occurred probably because SEY disturbed the general metabolism of the plant.

It is known that a sign of oxidative stress is one of the fastest defence responses of plants under various abiotic stress. Oxidative stress caused an imbalance between the formation of ROS and the detoxification of their reactive intermediates. Response of plants to this imbalance is crucial for maintaining high rates of photosynthesis and also for their survival before their cellular structures are damaged. In our studies, SEY was shown to induce oxidative stress in both the hybrid millet and Jingu 21, which is associated with molecular oxygen caused excess heat or electrons in chloroplasts. The herbicide SEY catalyzes the generation of superoxide radicals $\left(\mathrm{O}_{2}^{-}\right)$by accepting electrons from PSI, inhibiting the reduction of ferredoxin, which finally causes photooxidative stress (Xie et al. 2014, Wang et al. 2011). Previous reports have indicated that 3-aminotriazole can cause accumulation of $\mathrm{H}_{2} \mathrm{O}_{2}$ by inhibiting the catalase activity (Gechev et al. 2005 ). Both MDA content and $\mathrm{O}_{2}$ - production showed a significant increase in Jingu 21 after 7-d exposure to 0.75, $1.5,3$, and $6 \mathrm{~L}$ (ai) $\mathrm{ha}^{-1}$, suggesting that SEY application to sensitive species stimulated ROS production to concentrations that could overwhelm the detoxification process. However, the hybrid millet varieties (Zhangza) showed no significant differences with SEY at 0.75 and $1.5 \mathrm{~L}$ (ai) ha ${ }^{-1}$ after $7 \mathrm{~d}$ of exposure and in fact, it showed some recovery after $15 \mathrm{~d}$ of exposure. This might be the reason that 

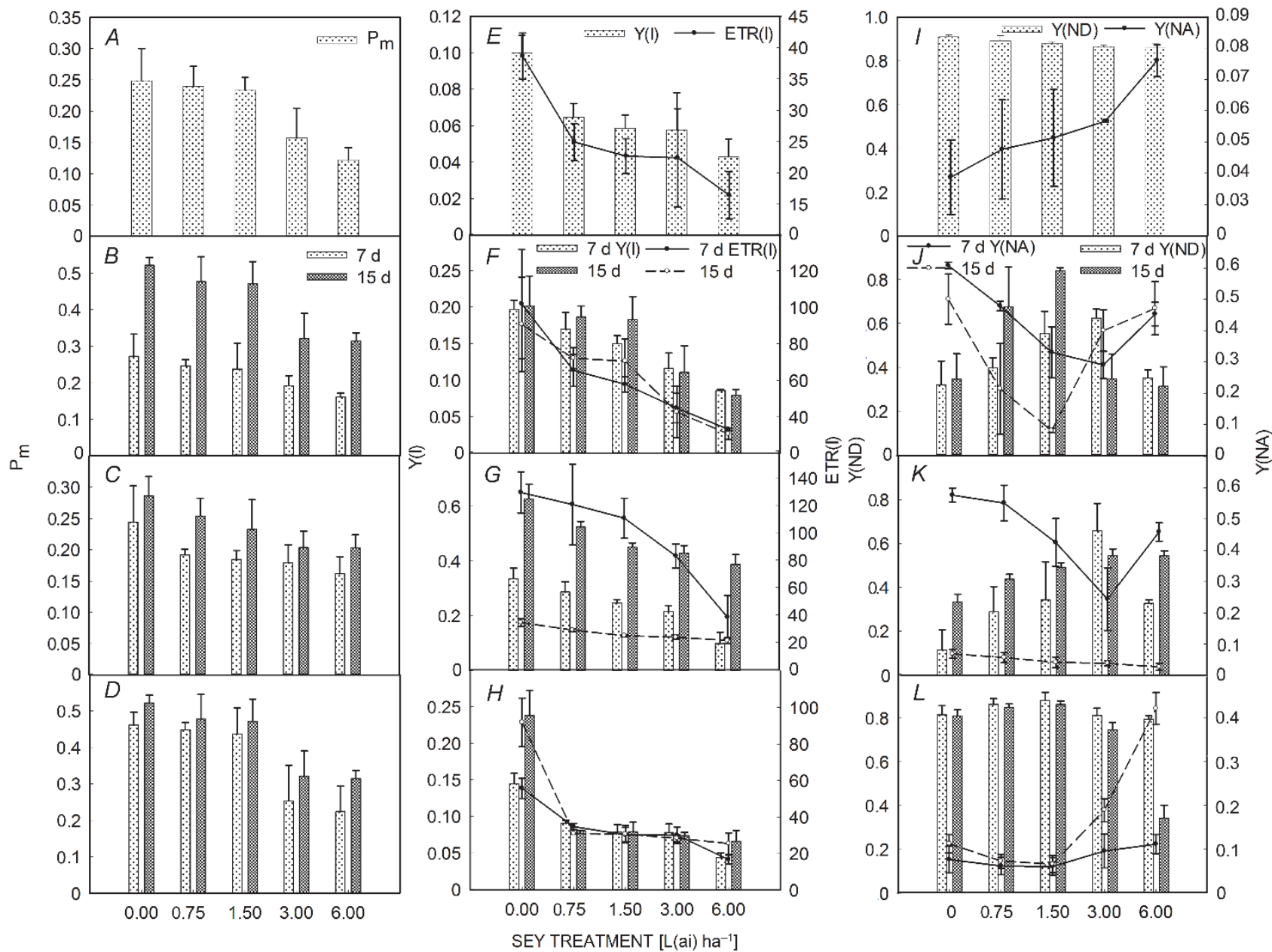

Fig. 4. Effect of sethoxydim (SEY) on PSI parameters in leaves of foxtail millet seedlings. PSII parameters of Jingu 21 were assessed after $7 \mathrm{~d}$ of exposure to SEY and PSII parameters of Zhangza 3, Zhangza 5, and Zhangza 10 were assessed after $7 \mathrm{~d}$ and $15 \mathrm{~d}$ of exposure to SEY. $P_{m}$ - maximal $P_{700}$ change; $Y_{I}$ - photochemical quantum yield of PSI; ETR - PSI electron transport rate; $Y_{N A}-$ quantum yield of nonphotochemical energy dissipation due to acceptor-side limitation in PSI; Y $\mathrm{ND}_{\mathrm{ND}}$ - quantum yield of nonphotochemical energy dissipation due to donor-side limitation in PSI. A,E,I-Jingu 21; B,F,J-Zhangza 3; C,G,K-Zhangza 5; D,H,L-Zhangza 10.

oxidative stress tolerance to SEY exposure is associated with a reduced ETR (Moustaka et al. 2014, Chase et al. 1998), due to enhancement of NPQ that reflects the dissipation of excess excitation energy in the form of harmless heat (down regulation of PSII), which protects the plant from the damaging effects of ROS (Hideg et al. 2008).

Content of photosynthetic pigments is an important indicator for reflecting plant photosynthesis. In this study, one of visible symptoms was chlorosis of leaves with SEY, which showed that Chl was affected by the SEY exposure. In Jingu 21 , the concentration of sethoxydim $(\geq 0.75 \mathrm{~L}$ $\mathrm{ha}^{-1}$ ) had a remarkable effect on the Chl content, which demonstrated that SEY destructed the chloroplast structure of foxtail millet leaves, increased the risk of photooxidation damage, reduced the light absorption, transmission, and distribution between PSII and PSI (Havaux et al. 1991), and affected the synthesis of ATP and NADPH. However, SEY treatment had less effect on the Chl content of the hybrid millets (Zhangza) than that of the Jingu 21.
Only the maximum dose (4-fold of the recommended dose) resulted in obviously lower values compared with controls. Thus, the difference of pigment content can explain the sensitivities among different plant species. Our results suggest that SEY might be active in the chloroplast electron-transport system and disturb the photosynthesis.

In this study, SEY treatment reduced the pigment content, indicating that the photosynthesis process was inhibited and the production of metabolic energy decreased simultaneously. Qian et al. (2014) demonstrated that $\mathrm{Chl}$ fluorescence is more sensitive to the herbicide treatment in plants than $\mathrm{Chl}$ content and other growth parameters. Previous experiments with a range of plants have demonstrated the wide applicability of Chl fluorescence for the detection of herbicide-induced perturbation of photosynthesis (Hjorth et al. 2006, Wang et al. 2011). Our results indicated that the decrease in $\mathrm{F}_{\mathrm{v}} / \mathrm{F}_{\mathrm{m}}$ and $\mathrm{F}_{\mathrm{v}} / \mathrm{F}_{0}$ in the four crop species during herbicide stress occurred mainly due to the photoinhibition, which indicates that the 
integrity of the PSII was affected and a large number of PSII reaction centers were destroyed (Krause et al. 1991). In the hybrid millet varieties, the value of $F_{v} / F_{m}$ was slightly lower than that of the control after the $7 \mathrm{~d}$, which indicated that the decrease in $\mathrm{F}_{\mathrm{v}} / \mathrm{F}_{\mathrm{m}}$ did not result in photodamage (Lu 2008). It may suggest that SEY caused reversible deactivation in the hybrid millet (Zhangza). However, after $15 \mathrm{~d}$ of exposure to SEY, Jingu 21 became dead due to photodamage and degradation of D1 protein (not measured in this study) (Tyystjärvi et al. 1996).

Previous studies with a range of plant species have demonstrated that herbicides cause damage to the PSII complex, block the electron transfer, reduce values of $\mathrm{F}_{\mathrm{v}} / \mathrm{F}_{\mathrm{m}}, \mathrm{F}_{\mathrm{v}} / \mathrm{F}_{0}, \mathrm{Y}_{\mathrm{II}}$, and $\mathrm{q}_{\mathrm{P}}$ significantly, and lead to increase in $\mathrm{q}_{\mathrm{N}}$ in wheat leaf (Wang et al. 2011). In this study, $\mathrm{Y}_{\mathrm{NO}}$ increased, whereas $F_{\mathrm{v}} / \mathrm{F}_{\mathrm{m}}, \mathrm{Y}_{\mathrm{II}}, \mathrm{ETR}_{\mathrm{II}}, \mathrm{q}_{\mathrm{P}}$, and $\mathrm{Y}_{\mathrm{NPQ}}$ decreased in leaves treated by SEY. In concordance with our results, Jones and Kirswell (2003) showed a similar effect after application of SEY on other plant species. Additionally, due to the difference in sensitivity of PSII and PSI to herbicides in the crop varieties, the degree of photoinhibition is not only dependent on the extent of the gross damage to the photosynthetic apparatus but also on the capacity for recovery (Huang et al. 2010). Our results showed that SEY stress did not damage PSII reaction centers of the hybrid millet because $\mathrm{Y}_{\mathrm{NPQ}}$ increased under the SEY (Fig. 2), which demonstrated that a fraction of the energy was passively dissipated in the form of heat and fluorescence, thus protecting the plant from the damaging effects of ROS. This increased NPQ seemed to serve as a quick effective photoprotection mechanism for the hybrid millet exposure to SEY. PSII function showed moderate recovery after SEY-induced photoinhibition for $15 \mathrm{~d}$ $\left(\leq 1.5 \mathrm{~L} \mathrm{ha}^{-1}\right)$, which is likely to be due to the fast turnover of D1 protein and the fact that most of the damaged PSII core subunits can be reused without de novo synthesis (van Wijk et al. 1995). However, Jingu 21 showed inhibited electron transport and did not show any recovery after SEY treatment after $15 \mathrm{~d}$ (Fig. $2 A, E, I, M)$, which could be due to photodamage, impaired linear electron flow, and degradation of D1 protein (not measured in this study) (Sun et al. 2006). Generally, insufficient dissipation of excess excitation energy can result in photo-oxidative stress, leading to the eventual formation of ROS (Smirnoff 1993). Our results indicated that the recovery from severe photoinhibition of PSII was related to higher photo-

\section{References}

Aicha B., Ghouziel B.K.: Sethoxydim treatment inhibits lipid metabolism and enhances the accumulation of anthocyanins in rape (Brassica napus L.) leaves. - Pestic. Biochem. Phys. 107: 120-126, 2013.

Brinson Conerly E.: Clethodim New Chemical Registration Standard. Pp. 1-66. United States Environmental Protection Agency, Washington 1990.

Chase C.A., Bewick T.A., Shilling D.G.: Differential photo- protective ability in this genotype. Therefore, these results showed that the appropriate dosage range of SEY used for the treatment had photoinhibition effect on the hybrid millet, but did not cause photodamage of the PSII.

Previous research has shown that the reduction in maximum oxidation-reduction ability of PSI is a typical feature of PSI photoinhibition (Scheller et al. 2005). In this study, SEY induced oxidative stress in foxtail millet via catalyzing the generation of superoxide radicals by accepting electrons from PSI, which resulted in photooxidative stress. As a result, $\mathrm{P}_{\mathrm{m}}, \mathrm{Y}_{\mathrm{I}}$, and ETR $_{\mathrm{I}}$ decreased with the increase in SEY dosages, and the hybrid millet showed recovery after $15 \mathrm{~d}$ of treatment at recommended dosage $\left(1.5 \mathrm{~L} \mathrm{ha}^{-1}\right)$. On one hand, the hybrid millet continued to grow under SEY stress probably because they developed a protective PSI mechanism, which blocked the linear electron flow from PSII to PSI, and thereby alleviated the photoinhibition of PSI under SEY (Miyake et al. 2005). On the other hand, $\mathrm{Y}_{\mathrm{ND}}$ reflects the state of electron donor in PSI, and it is affected by the transmembrane proton gradient and degree of damage PSII (Yuan et al. 2013). It was evident that $\mathrm{Y}_{\mathrm{ND}}$ for Jingu 21 reduced rapidly after the SEY treatment $\left(\geq 0.75 \mathrm{~L} \mathrm{ha}^{-1}\right)$, suggesting that SEY aggravated the damage of the PSII in Jingu 21 leaves, decreased the transmembrane proton gradient, blocked the dark reaction process, and reduced the fixed amount of $\mathrm{CO}_{2}$. However, $\mathrm{Y}_{\mathrm{ND}}$ increased at SEY concentrations $\leq 1.5 \mathrm{~L} \mathrm{ha}^{-1}$ for the hybrid millet, suggesting that these hybrid millet varieties could well protect themselves from photodamage by improving the heat dissipation. Additionally, $\mathrm{Y}_{\mathrm{NA}}$ reflects the state of electron acceptor in PSI, and it is affected by dark adaptation and level of damage to $\mathrm{CO}_{2}$ fixation (Yuan et al. 2013). The $\mathrm{Y}_{\mathrm{NA}}$ for Jingu 21 increased with SEY exposure from 0.75 to $6 \mathrm{~L} \mathrm{ha}^{-1}$, indicating severe photooxidative stress on PSI reaction centers.

Conclusion: It was found that the recommended dosage of SEY (1.5 L ha ${ }^{-1}$ ) was not safe for Jingu 21, as it caused the damage of chloroplasts, PSI and PSII structures, and blocked the dark reaction process. In contrast, the hybrid millet varieties (Zhangza) showed a greater tolerance to SEY and also had the ability to recover. The appropriate dosage range of SEY treatment caused reversible deactivation in the hybrid millet, but did not cause any photodamage to the photosystems.

synthetic electron transport and oxidative stress in paraquatresistant and sensitive biotypes of Solanum americanum. Pestic. Biochem. Phys. 60: 83-90, 1998.

Dong B., Liu M., Jiang J. et al.: Growth, grain yield, and water use efficiency of rain-fed spring hybridmillet (Setaria italica) in plastic-mulched and unmulched fields. - Agr Water Manage. 143: 93-101, 2014

Edwards D.: Reregistration Eligibility Decision (RED) for 
Sethoxydim. Pp. 1-27. United States Environmental Protection Agency, Washington 2005.

Elstner E.F., Heupel A.: Inhibition of nitrite formation from hydroxylammonium chloride: A simple assay for superoxide dismutase. - Anal. Biochem. 70: 616-620, 1976.

Gechev T.S., Minkow I.N., Hille J.: Hydrogen peroxide-induced cell death in Arabidopsis transcriptional and mutant analysis reveals a role of an oxoglutarate-dependent dioxygenase gene in the cell death process. - IUBMB Life 5: 181-188, 2005.

Havaux M., Strasser R.J., Greppin H.: A theoretical and experimental analysis of the $\mathrm{qP}$ and $\mathrm{qN}$ coefficients of chlorophyll fluorescence quenching and their relation to photochemical and nonphotochemical events. - Photosynth. Res. 27: 41-55, 1991.

Heath R.L., Packer L.: Photoperoxidation in isolated chloroplasts I. Kinetics and stoichiometry of fatty acid peroxidation. - Arch. Biochem. 125: 189-198, 1968.

Hideg É., Kós P., Schreiber U.: Imaging of NPQ and ROS formation in tobacco leaves: heat inactivation of the waterwater cycle prevents down-regulation of PSII. - Plant Cell Physiol. 49: 1879-1886, 2008.

Hjorth M., Mondolot L., Buatois B. et al.: An easy and rapid method using microscopy to determine herbicide effects in Poaceae weed species. - Pest. Manag. Sci. 62: 515-521, 2006.

Huang W., Zhang S.B., Cao K.F.: The different effects of chilling stress under moderate light intensity on photosystem II compared with photosystem I and subsequent recovery in tropical tree species. - Photosynth. Res. 103: 175-182, 2010.

Jones R., Kerswell A.P.: Phytotoxicity of photosystem II (PSII) herbicides to coral. - Mar. Ecol.-Prog. Ser. 261: 149-159, 2003.

Kamara M.T., Huiming Z., Kexue Z. et al.: Comparative study of chemical composition and physicochemical properties of two varieties of defatted foxtail millet flour grown in China. Am. J. Food Technol. 4: 255-267, 2009.

Klughammer C., Schreiber U.: Saturation Pulse method for assessment of energy conversion in PS I. - PAM Appl. Notes 1: 11-14, 2008.

Kocurek V., Smutný V., Filová J.: Chlorophyll fluorescence as an instrument for the assessment of herbicide efficacy. - Cereal Res. Commun. 37: 289-292, 2009.

Kopsell D.A., Armel G.R., Abney K.R. et al.: Leaf tissue pigments and chlorophyll fluorescence parameters vary among sweet corn genotypes of differential herbicide sensitivity. Pestic. Biochem. Phys. 99: 194-199, 2011.

Kramer D.M., Johnson G., Kiirats O. et al.: New fluorescence parameters for the determination of $\mathrm{Q}_{\mathrm{A}}$ redox state and excitation energy fluxes. - Photosynth. Res. 79: 209-218, 2004.

Krause G.H., Weis E.: Chlorophyll fluorescence and photosynthesis: the basis. - Annu. Rev. Plant Biol. 42: 313-349, 1991.

Lichtenthaler H.K.: Chlorophylls and carotenoids: pigments of photosynthetic biomembranes. - Methods Enzymol. 148: 350382, 1987.

Lu K.X., Yang Y., He Y. et al.: Induction of cyclic electron flow around photosystem I and state transition are correlated with salt tolerance in soybean. - Photosynthetica 46: 10-16, 2008.

Miyake C., Horiguchi S., Makino A. et al.: Effects of light intensity on cyclic electron flow around PSI and its relationship to non-photochemical quenching of chl fluorescence in tobacco leaves. - Plant Cell Physiol. 46: 1819-1830, 2005.

Moustaka J., Moustakas M.: Photoprotective mechanism of the non-target organism Arabidopsis thaliana to paraquat exposure. - Pestic. Biochem. Phys. 111: 1-6, 2014.

Moustakas M., Malea P., Zafeirakoglou A. et al.: Photochemical changes and oxidative damage in the aquaticmacrophyte Cymodocea nodosa exposed to paraquat-induced oxidative stress. - Pestic. Biochem. Phys. 126: 28-34, 2016.

Opeña J.L., Quilty J.R., Correa T.Q. et al.: Weed population dynamics, herbicide efficacies, and crop performance in a sprinkler-irrigated maize-rice cropping system. - Field Crop. Res. 167: 119-130, 2014.

Pfündel E., Klughammer C., Schreiber U.: Monitoring the effects of reduced PS II antenna size on quantum yields of photosystems I and II using the Dual-PAM-100 measuring system. - PAM Appl. Notes. 1: 21-24, 2008.

Qian H.F., Tsuji T., Endo T. et al.: The PGR5 and NDH pathways in photosynthetic cyclic electron transfer respond differently to sub-lethal treatment with photosystem-interfering herbicides. J Agric. Food Chem. 62: 4083-4089, 2014.

Sandín-España P., Sevilla-Morán B., López-Goti C et al:: Rapid photodegradation of clethodim and sethoxydim herbicides in soil and plant surface model systems. - Arab. J. Chem. 9: 694703, 2015.

Scheller H.V., Haldrup A.: Photoinhibition of photosystem I. Planta 221: 5-8, 2005.

Smirnoff N.: The role of active oxygen in the response of plants to water-deficit and desiccation. - New Phytol. 125: 27-58, 1993.

Stoltz E., Nadeau E.: Effects of intercropping on yield, weed incidence, forage quality and soil residual $\mathrm{N}$ in organically grown forage maize (Zea mays L.) and faba bean (Vicia faba L.). - Field Crop. Res. 169: 21-29, 2014.

Sun Z.L., Lee H.Y., Matsubara S. et al:: Photoprotection of residual functional photosystemII units that survive illumination in the absence of repair, and their critical role in subsequent recovery. - Physiol. Plantarum 128: 415-424, 2006.

Tan W., Li Q.L., Zhai H.: Photosynthesis and growth responses of grapevine to acetochlor and fluoroglycofen. - Pestic. Biochem. Phys. 103: 210-218, 2012.

Tyystjärvi E., Aro E.M.: The rate constant of photoinhibition, measured in lincomycin-treated leaves, is directly proportional to light intensity. - P. Natl. Acad. Sci. USA 93: 2213-2218, 1996.

van Wijk K.J., Bingsmark S, Aro EM et al.: In vitro synthesis and assembly of photosystem II core proteins. - J. Biol. Chem. 270: 25685-25695, 1995.

Wakabayashi K.O., Böger P.: Phytotoxic sites of action for molecular design of modern herbicides (Part 1): the photosynthetic electron transport system. - Weed Biol. Manag. 4: 8-18, 2004.

Wang T.Y., Darmency H.: Inheritance of sethoxydim resistance in foxtail millet (Setaria italica (L.) Beauv.). - Euphytica 94: 69-73, 1997.

Wang T.Y., Xin Z.Y., Shi Y.T. et al.: [A creation, evaluation and utilization of the new crop germplasm: herbicide resistance foxtail millet (Setaria italica).]. - J. Agr. Sci. Technol. 2: $62-$ 66, 2000. [In Chinese].

Wang X., Li J., Xing H. et al.: [Review of toxicology of atrazine and chlorpyrifos on fish.]. - J. Northeast Agric. Univ. 18: 8892, 2011. [In Chinese].

Wang X., Rong E.H., Zhang J.H. et al.: Effect of quizalofop on protective enzymes and photosynthesis in Radix Isatidis. - J. Med. Plants Res. 6: 1770-1776, 2012.

Wang Z.G., Zhou L.Y., Guo W.S. et al.: [Effects of herbicides on photosynthesis and chlorophyll fluorescence parameters in wheat leaves.]. - J. Agro-Environ. Sci. 30: 1037-1043, 2011. [In Chinese]. 
Xie L.L., Guo P.Y., Yuan X.Y. et al.: [Effect of sethoxydimon on physiological characteristics of hybrid millet Zhangzagu 5 seedling.] - J. Shanxi Agric. Sci. 42: 223-226, 2014. [In Chinese].

Yuan X.Y., Guo P.Y., Qi X. et al:: Safety of herbicide Sigma Broad on Radix Isatidis (Isatis indigotica Fort.) seedlings and their photosynthetic physiological responses. - Pestic. Biochem. Phys. 106: 45-50, 2013.

Zhang G.Y., Liu X., Quan Z.W. et al.: Genome sequence of foxtail millet (Setaria italica) provides insights into grass evolution and biofuel potential. - Nat. Biotechnol. 30: 549-556, 2012.

Zhang Y.P., Jia F.F., Zhang X.M. et al.: Temperature effects on the reactive oxygen species formation and antioxidant defence in roots of two cucurbit species with contrasting root zone temperature optima. - Acta Physiol. Plant. 34: 713-720, 2012.

Zhao R., Guo P.Y., Yuan X.Y. et al.: Effect of paraquat on the antioxidative enzyme activities and lipid peroxidation in opium poppy (Papaver somniferum L). - J. Plant Dis. Protect. 117: $55-59,2010$. 